\title{
Nanotechnology based Mega Machine Design for Large Scale Air Cleaning - Prospects and Challenges
}

\author{
Shubhrajyotsna Aithal ${ }^{1 *}$ \& P. S. Aithal ${ }^{2}$ \\ ${ }^{1 *}$ Faculty, College of Engineering \& Technology, Srinivas University, Mangalore, INDIA \\ OrcidID: 0000-0003-1081-5820; E-mail: shubhraaithal@gmail.com \\ ${ }^{2}$ Centre for Technology Prediction \& Forecasting, Srinivas University, Mangalore - 575 001, INDIA \\ OrcidID: 0000-0002-4691-8736; E-mail: psaithal@gmail.com
}

Area of the Paper: Environment Science.

Type of the Paper: Research Paper.

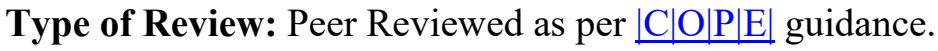

Indexed In: OpenAIRE.

DOI: $\underline{\text { http://doi.org/10.5281/zenodo.4409579 }}$

Google Scholar Citation: IJCSBE.

\section{How to Cite this Paper:}

Shubhrajyotsna Aithal \& Aithal, P. S. (2020). Nanotechnology based Mega Machine Design for Large Scale Air Cleaning - Prospects and Challenges. International Journal of Case Studies in Business, IT, and Education (IJCSBE), 4(2), 250-269. DOI: http://doi.org/10.5281/zenodo.4409579.

International Journal of Case Studies in Business, IT and Education (IJCSBE)

A Refereed International Journal of Srinivas University, India.

(C) With Authors.

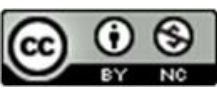

This work is licensed under a Creative Commons Attribution Non-Commercial 4.0 International License subject to proper citation to the publication source of the work.

Disclaimer: The scholarly papers as reviewed and published by the Srinivas Publications (S.P.), India are the views and opinions of their respective authors and are not the views or opinions of the S.P. The S.P. disclaims of any harm or loss caused due to the published content to any party. 


\title{
Nanotechnology based Mega Machine Design for Large Scale Air Cleaning - Prospects and Challenges
}

\author{
Shubhrajyotsna Aithal ${ }^{1 *}$ \& P. S. Aithal ${ }^{2}$ \\ ${ }^{1 *}$ Faculty, College of Engineering \& Technology, Srinivas University, Mangalore, INDIA \\ OrcidID: 0000-0003-1081-5820; E-mail: shubhraaithal@gmail.com \\ ${ }^{2}$ Centre for Technology Prediction \& Forecasting, Srinivas University, Mangalore - 575 001, INDIA \\ OrcidID: 0000-0002-4691-8736; E-mail: psaithal@gmail.com
}

\begin{abstract}
Air pollution is a major component of environmental degradation in the $21^{\text {st }}$ century worldwide due to the increased use of fossil fuels in various industries and their contribution to contaminating the natural atmosphere around us. Environmental pollution is posing a challenge to human existence and the continuation of human generation on this planet. Environmental degradation is considered a major affecting factor of climate change which includes both global warming driven by industrial emissions of green gases and large-scale shift in weather patterns.

This problem is growing on a large scale throughout the world and poses challenges to survival and sustainability. Nanotechnology being universal technology can be used to solve this problem of environmental degradation by cleaning the degraded air on large scale and can counter the contribution of natural and industrial pollution. In this paper, the proposal of construction and use of nanotechnology based mega machine is analyzed and the prospectus and challenges of such machine production and maintenance for large scale air cleaning are discussed. The advantages, benefits, constraints, and disadvantages of production and use of such mega machines from various stakeholders' points of view are identified. Finally, the idea of self-sustainable nanotechnology filters based mega machines is proposed using solar/wind energy supported systems for automatic and self-sustainable use.
\end{abstract}

Keywords: Nanotechnology, Nanomaterial air filters, Mega machines, Large scale air cleaning, Solar energy, sustainable use

\section{INTRODUCTION:}

The basic needs of human beings in society include nutritious food, potable drinking water, renewable energy, sustained health, and a clean and green environment. Due to uncontrolled industrialization and greediness of many people, the environment is currently degraded by means of air pollution, water pollution, and food pollution, leading to environmental degradation. Air pollution is a major component of environmental degradation in the $21^{\text {st }}$ century worldwide due to the increased use of fossil fuels in various industries and their contribution to contaminating the natural atmosphere around us. Environmental pollution is posing a challenge to human existence and the continuation of human generation on this planet. Environmental degradation is considered a major affecting factor of climate change, which includes both global warming driven by industrial emissions of green gases and resulting in large scale shifts in weather patterns. This problem is growing on a large scale throughout the world and posing challenges to the survival and sustainability of all living beings. Environment degradation is associated with a reduction in the quality of environmental features due to various human activities in the name of civilization and development along with natural disasters [1]. The continuously increasing environmental degradation in an uncontrollable manner leads to depletion of natural resources, affecting biodiversity and ecosystems. Out of various types of environmental pollutions, air pollution and water pollution have major consequences on human life on this planet. It is known that air pollution usually occurs due to the addition of toxic substances and chemicals emitted from various activities like fossil fuel consumption, industrial wastes, emissions from automobiles, etc to the natural atmosphere [2]. Acute air pollution creates many health-related problems including acute respiratory effects [3]. Hence it is essential to think of the development of a system to clean the environment on a large scale along with controlling the causes of pollution to ensure the survival of all life on earth. Cleaning the environment systematically can reduce pollution, protect unique ecosystems, protects the extinction of living species, and conserves clean air and potable water. Cleaning 
the environment allows us to protect biodiversity and ecosystems and hence living creatures on earth. It is estimated that climate change and global warming will be at their peak during the end of the $21^{\text {st }}$ century and if the precautions are not taken from now life on earth may extinguish due to various environment related disasters. These disasters like drought, heavy rainfalls and floods, melting ice caps and increasing sea levels, circulation of heatwaves, etc lead to further climate change and weather change. Manmade pollutants other than conventional pollutants, like toxic emissions and carbon dioxide emissions from various industries and motor vehicles, contribute to air pollution. These manmade pollutants along with conventional pollutants adversely affect and toxic human health, causing health hazards such as cholera, eye irritation, heart disease, cancer, and respiratory diseases leading to an increased rate of mortality [4].

It is understood that technology if used properly can support human beings to solve many problems. Water \& Steam Power Systems using Mechanization technology for producing energy were supported Industry 1.0, Electricity and assembly line systems using Mass Production knowledge based technology were supported Industry 2.0, Computer and Communication technology systems which were skill based Automation Processes supported Industry 3.0, Internet of Things (IoT) and 3D printing systems used for Mass Customization supporting Industry 4.0, and ICCT underlying technologies including Artificial intelligence \& Virtual reality and Nanotechnology will be used for mass automation and 3D production using ICCT controlled Super Intelligent Machine systems and Nanotechnology results in Industry 5.0. [5]. Though nanotechnology is got its birth during the second part of the $20^{\text {th }}$ century, it is considered as the breakthrough technology of the $21^{\text {st }}$ century [6] due to its potential ability to solve basic needs related, wants related, and desire related problems of human beings $[7,8]$. Nanotechnology has initiated breakthrough changes in many major industries including agriculture $\&$ food processing [9], Potable water [10], renewable energy [11], Automobiles [12], and healthcare sectors [13]. It is predicted that nanotechnology has many features of green technology $[14,15]$ and is capable of realizing many characteristics of ideal technology [16].

Nanotechnology being universal technology $[17,18]$ can be used to solve the problem of environmental degradation by cleaning the degraded air on large scale and can counter the contribution of natural and industrial pollution. Recently our team (Shubhrajyotsna Aithal et al (2020)) has published an idea of using mega machines as air and water cleaners for cleaning the environment using Nanotechnology [2] and listed its advantages, benefits, constraints, and disadvantages. In this paper, the proposal of construction and use of nanotechnology based mega machine is analyzed and the prospectus and challenges of such machine production and maintenance for large scale air cleaning are discussed. The advantages, benefits, constraints, and disadvantages of production and use of such mega machines from various stakeholders' points of view are identified. Finally, the idea of self-sustainable nanotechnology filters based mega machines is proposed using solar/wind energy supported systems for automatic and self-sustainable use.

\section{RELATED WORKS:}

Rickerby, D. G., et al. (2007) [19] argued that nanotechnology has the capability to provide more sensitive detection systems for air and water quality monitoring and control. Metal oxide nanocatalysts are potential candidates to prevent and control air pollution due to industrial emissions. They also proposed that it is possible to prevent air pollution due to industrial emissions using carbon nanotubes and the photocatalytic properties of titanium dioxide nanoparticles can be used to create self-cleaning surfaces that reduce existing air pollution.

Muller, C. O. et al (2015) [20] studied the effect of air pollution on morbidity and mortality in China and suggested the use of air cleaning systems to remove irritating and noxious gases and foul odours along with a respirable particulate matter to protect people health and to ensure good indoor air quality. They suggested using leading-edge air cleaning technologies including nanotechnology to effectively remove common air pollutants including $\mathrm{PM}_{10}, \mathrm{PM}_{2.5}$, formaldehyde, $\mathrm{O}_{3}, \mathrm{SO}_{2}, \mathrm{NO}_{2}$, and volatile organic compounds.

Yunus, I. S., et al (2012) [21] discussed various types of pollutants emitted from human activities or industrial processes. They also suggested the use of nanomaterials like carbon nanotubes and gold particles to remove toxic gases in the polluted air using the process of adsorption. This includes adsorption of dioxins and related compounds which are toxin in nature to humans and mainly generated from the combustion of organic 
compounds in waste incineration, adsorption of $\mathrm{NO}_{x}$ (mixture of $\mathrm{NO}$ and $\mathrm{NO}_{2}$ ) using carbon nanotubes (CNT), Capture of carbon dioxide $\left(\mathrm{CO}_{2}\right)$ using chemically modified CNTs, silica-based molecular baskets, Removal of other volatile organic compounds (VOCs) using highly porous manganese oxide with gold nanoparticles, Adsorption of isopropyl alcohol (IPA) vapour using Single walled carbon nanotubes (SWCNTs) oxidized by a solution of $\mathrm{HNO}_{3}$ and $\mathrm{NaClO}$, etc.

Aithal, S., et al (2020) [2] provided an idea for designing Mega-Machine for environmental cleaning of air with discussion related to causes of environmental pollution, constituents of polluted air and water, various technologies suitable for environmental cleaning, and ability of nanotechnology in air and water cleaning processes. The design idea includes a mega device to clean the polluted air using nanotechnology based filters. The suitability of the device is analyzed by listing its advantages, benefits, constraints, and disadvantages and suggested the pre-cautions to be taken while implementing such cleaning devices.

\section{OBJECTIVES:}

(1) To evaluate the need for mega air cleaner in industrial and public places to counter the climate change

(2) To discuss the technological solutions to air pollution

(3) To use of Nanotechnology to develop Mega-Machine for Environmental Air Cleaning

(4) To evaluate the functions of Nano-filters-based mega machine proposed earlier for large scale air cleaning

(5) To provide further details of mega air cleaners in terms of various polluting components.

(6) To analyze the prospects of such mega machines in the process of controlling climate change

(7) To suggest the use of renewable energy for self-sustainability of air cleaning mega machines.

(8) To discuss the challenges of developing mega air cleaning machines of variable size from design, construction, and maintenance points of view.

(9) To study the importance of such machines using ABCD Analysis framework from Various Stakeholders Point of Views.

(10) To suggest the precautions for implementation of such mega cleaning Devices and their suitability of fulfilling $17^{\text {th }}$ goal of United Nations SDG.

\section{NEED OF MEGA AIR CLEANER:}

According to a damning report on outdoor air quality by the World Health Organization (WHO), almost 90\% of people living in the cities are currently exposed to dangerous levels of air pollution. Based on its studies, out of 1,600 cities across 91 countries, only $12 \%$ of cities have complied with the guidelines of WHO and others have dangerous air pollution levels. Table 1 depicts the pollution index of 20 countries in the world map for the year 2020. Pollution Index is an estimation of the overall pollution in a city which includes air pollution (maximum weight), water pollution, and other types of pollution (minimum weight). It is recognized that carbon, sulphur, nitrogen compounds, ground level ozone, and particulate matter (PM) pollution produced by anthropogenic and of natural origin pose serious health risks.

Table 1 : Top 20 countries having highest pollution index as in Mid of 2020

\begin{tabular}{||c|c|c|}
\hline \multicolumn{1}{|c|}{ Rank } & Country & Pollution Index \\
\hline \hline 1 & Afghanistan & 93.47 \\
\hline \hline 2 & Mongolia & 92.03 \\
\hline \hline 4 & Myanmar & 91.58 \\
\hline \hline 5 & Lebanon & 88.91 \\
\hline 6 & Ghana & 88.51 \\
\hline \hline 7 & Nigeria & 86.89 \\
\hline \hline 8 & Monaco & 86.53 \\
\hline
\end{tabular}




\begin{tabular}{||l||c|c|}
\hline \multicolumn{1}{|c|}{ Rank } & Country & Pollution Index \\
\hline \hline 9 & Bangladesh & 85.83 \\
\hline \hline 10 & Nepal & 84.80 \\
\hline \hline 11 & Egypt & 84.69 \\
\hline \hline 12 & Peru & 83.34 \\
\hline \hline 13 & North Macedonia & 80.23 \\
\hline \hline 14 & China & 79.88 \\
\hline \hline 15 & Ethiopia & 79.87 \\
\hline \hline 16 & Chile & 79.74 \\
\hline \hline 17 & India & 79.56 \\
\hline \hline 18 & Albania & 78.24 \\
\hline \hline 19 & Cambodia & 78.00 \\
\hline \hline 20 & Laos & 79 \\
\hline
\end{tabular}

Reference: https://www.numbeo.com/pollution/rankings_by_country.jsp

The outdoor air pollution is one of the world's largest environmental problems due to industrialization of the countries and their transition from low to middle income countries. This leads to health related diseases and counts for 3.4 million premature deaths in the year 2017. These data are really threatening human health and decrease the life span too. The study of pollution levels all along with the world especially in cities suggests the immediate action using technology. Further, the development and installation of mega air cleaners in identified areas help to achieve five out of seventeen United Nations Sustainable Development Goals (SDGs) which include (1) Ensuring healthy lives and well-being for all at all ages by means of pollution free atmosphere (Goal 3), (2) To ensure availability and sustainable management of potable water and sanitation for all by controlling all kind of pollution which degrade potable water (Goal 6), (3) To build resilient infrastructure, promote inclusive and sustainable industrialization and foster innovation by controlling industrial pollution (Goal 9), (4) To make cities and human settlements inclusive, safe, resilient, and sustainable by controlling the pollution in the cities (Goal 11), and (5) To take urgent action to combat climate change and its impact by means of controlling all type of pollutions and environmental degradation (Goal 13).

\section{NANOMATERIALS USED FOR CLEANING OF AIR-POLLUTANTS:}

Nanotechnology is the application of nanoscience where the materials of the dimensions of the order of $10^{-9} \mathrm{~m}$ show special physical and chemical characteristics including electrical conductivity, mechanical strength, colour, etc. are different from their bulk properties. For example, some metals at the nanoscale size behave like semiconductors or insulators. This is due to either increased surface area to volume ratio, or increased mechanical strength, or improved thermal stability, or varied catalytic activity, or changed electrical conductivity, magnetic properties, and optical properties. These special properties of nanomaterials allow the users to prepare lightweight but very strong nano-systems for device fabrications including nano-purifier both for indoor and outdoor air purifications. These air purifiers use three types of principles identified as Adsorption based nano-purifiers, Degradation based nano-purifiers, and Filtration based nano-purifiers [2].

In adsorption based air purifiers, nanomaterial acts as a super adsorbent for several air pollutants due to their high selectivity, affinity, and capacity adsorption of harmful gases and volatile organics using their hydrogen bonding, electrostatic forces, $\pi-\pi$ interactions, and van der Waals forces. For example, carbon nanotubes deposited on quartz filters are used to eliminate and monitor volatile organic compounds (VOCs) and other air 
pollutants by means of adsorption [22]. Adsorption based air purifiers also capable to remove dioxin related compounds. It is known that Dioxin and related compounds (e.g. polychlorinated dibenzofuran and polychlorinated biphenyls) are stable and highly toxic pollutants. Dioxin compounds are mainly generated from the combustion of organic compounds in waste incineration. Through the adsorption process, carbon nanotubes are effective to remove dioxin from impure air. Similarly, $\mathrm{No}, \mathrm{SO}_{2}$, and $\mathrm{CO}_{2}$ are also adsorbed by carbon nanotubes.

In degradation based air purifiers, nanocatalysts are used for reducing air pollutants in the air. Compared to conventional catalysts, nanocatalytic system allows rapid and selective chemical transformations with an efficient yield at output along with the opportunity of catalyst recovery. It is found that using the principle of oxidization, photocatalysts are able to oxidize organic pollutants into nontoxic materials. At a sufficient level of light irradiation, the charge transfer process will occur from the valence band to the conduction band causing the surrounding substance to be oxidized. Many nanomaterials serve as efficient photocatalysts. For example, titanium dioxide $\left(\mathrm{TiO}_{2}\right)$, zinc oxide $(\mathrm{ZnO})$, and tungsten oxide $\left(\mathrm{WO}_{3}\right)$ are tested as efficient photocatalysts in many cases [23]. Degradation is also possible with highly porous manganese oxide with gold nanoparticles that are grown into it. Titanium dioxide $\left(\mathrm{TiO}_{2}\right)$ when being irradiated with ultraviolet (UV) light creates an excitedstate of the electron $\left(\mathrm{e}^{-}\right)$and hole $\left(\mathrm{h}^{+}\right)$pairs which are able to react with $\mathrm{O}_{2}$ and water vapor in the atmosphere to produce superoxide ions $\left(\mathrm{O}_{2}{ }^{-}\right)$and hydroxyl radicals $\left(\mathrm{OH}^{*}\right)$. Both $\mathrm{O}_{2}{ }^{-}$and $\mathrm{OH}^{*}$ are extremely powerful agents in destroying chemical compounds as well as bacterial cells to form $\mathrm{CO}_{2}$ and $\mathrm{H}_{2} \mathrm{O}$ [24- 30].

The filtration based air purifier uses nanometer sized membranes that have pore sizes from 1-10 nanometers. Membranes used are predominantly created from polymer thin films. Materials that are commonly used include polyethylene terephthalate or metals such as aluminum. Nanofiltration uses pressure as the driving force. Nanofiltration membranes provide higher thrust or rejection of multivalent ions, pesticides and heavy metals compared with conventional treatment methods and act as high-efficiency particulate air filters. Silver nanoparticles are used for nanofiltration because of their antibacterial properties and low toxicity to mammalian cells. Nanosilver is incorporated into different filtering membranes through various impregnation techniques. Two types of nanotechnology filters are (1) Carbon tube membrane filters, and (2) Nanofiber filters.

Table 2 depicts the causes of air pollution, its constituents, and the consequences as listed in reference [2]. Table 3 lists various nanomaterials used in air filters and Table 4 gives ideas about air filters of different materials.

Table 2 : Causes of Air Pollution and its constituents [2]

\begin{tabular}{|c|c|c|c|}
\hline S. No. & Cause for Air pollution & $\begin{array}{l}\text { Affecting Constituents of } \\
\text { polluted Air }\end{array}$ & Consequences \\
\hline 1 & Particulate Matter & $\begin{array}{l}\text { Gaseous primary pollutants } \\
\text { and compounds in } \\
\text { photochemical smog. }\end{array}$ & $\begin{array}{l}\text { Respiratory Problems } \\
\text { leading to Infant } \\
\text { mortality }\end{array}$ \\
\hline 2 & Persistent free radicals & Airborne fine particles & $\begin{array}{l}\text { Cardiopulmonary disease } \\
\text { leading Death }\end{array}$ \\
\hline 3 & Toxic Metals & Lead, Mercury, etc. & $\begin{array}{l}\text { Brain function leading to } \\
\text { Death }\end{array}$ \\
\hline 4 & Radioactive pollutants & High energy radiations \& ions & Possibly tuberculosis \\
\hline 5 & Traffic pollution & $\mathrm{CO}, \mathrm{NOx}$ & $\begin{array}{l}\text { Poisoning and fatalities, } \\
\text { including Eutrophication }\end{array}$ \\
\hline 6 & Biomass fuel & Greenhouse gases & $\begin{array}{l}\text { Higher incidence of } \\
\text { pneumonia }\end{array}$ \\
\hline 7 & $\begin{array}{l}\text { Volatile Organic } \\
\text { Compounds (VOCs) }\end{array}$ & $\begin{array}{l}\text { Methane }\left(\mathrm{CH}_{4}\right) \text { and non- } \\
\text { methane (NMVOCs) like } \\
\text { benzene, toluene and xylene }\end{array}$ & $\begin{array}{l}\text { Leukaemia through } \\
\text { prolonged exposure }\end{array}$ \\
\hline 8 & Ammonia $\left(\mathrm{NH}_{3}\right)$ & $\begin{array}{l}\text { Emitted from agricultural } \\
\text { processes }\end{array}$ & Caustic and hazardous \\
\hline
\end{tabular}


Table 3 : Nanomaterials used in Air filters [2]

\begin{tabular}{|c|c|c|c|}
\hline $\begin{array}{l}\text { S. } \\
\text { No. }\end{array}$ & Nanomaterial Used & Pollutants & Reference \\
\hline 1 & Carbon nanotubes & $\mathrm{N}_{2}, \mathrm{CO}, \mathrm{CO}_{2}$ & $\begin{array}{l}\text { Li, P. et al. (2014) [31-32 } \\
66-67]\end{array}$ \\
\hline 2 & Silica Nanoparticles & $\mathrm{Pb}$ (Lead) & $\begin{array}{l}\text { Saleh, T. A. (2016) [33 } \\
68]\end{array}$ \\
\hline 3 & Nanocellulose aerogel & VOCs (Aniline \& Benzene) & $\begin{array}{l}\text { Nemoto, J. et al. (2015) } \\
{[3469]}\end{array}$ \\
\hline 4 & $\mathrm{ZnO}$ nanorods & $\mathrm{CS}_{2}$ (Carbon Disulphide) & $\begin{array}{l}\text { Zhong, Z. et al. (2015) } \\
{[35-3670-71]}\end{array}$ \\
\hline 5 & Silver Nanoparticles & CO (Carbon monoxide) & $\begin{array}{l}\text { Siva, S. et al. (2015) } \\
{[3772]}\end{array}$ \\
\hline 6 & Titanium dioxide $\left(\mathrm{TiO}_{2}\right)$ & $\mathrm{SO}_{2}$, Ethylene & $\begin{array}{l}\text { Baltrusaitis, J. et al. } \\
(2011)[3873]\end{array}$ \\
\hline 7 & Tungsten oxide $\left(\mathrm{WO}_{3}\right)$ & NOx Sensing & $\begin{array}{l}\text { Wang, C. et al. (2014) } \\
{[3974]}\end{array}$ \\
\hline 8 & Nanofibers of natural protein & $\begin{array}{l}\text { Particulate pollutants and } \\
\text { toxic gases }\end{array}$ & $\begin{array}{l}\text { Souzandeh, H. et al. } \\
\text { (2016) }[4075]\end{array}$ \\
\hline 9 & Gold nanoparticles & Bacterial removal & $\begin{array}{l}\text { García, A. et al. (2012) } \\
{\left[\begin{array}{ll}41 & 76\end{array}\right]}\end{array}$ \\
\hline
\end{tabular}

Table 4: Air filters of different materials

\begin{tabular}{|c|c|c|c|}
\hline S. No. & Types of filters & Filtrate & Reference \\
\hline 1 & $\begin{array}{l}\text { Multifunctional and Efficient } \\
\text { Air Filtration }\end{array}$ & $\begin{array}{l}\text { Natural Nanofilter Prepared } \\
\text { with Zein and Polyvinyl } \\
\text { Alcohol }\end{array}$ & $\begin{array}{l}\text { Li, K. et al. (2020) } \\
{[42]}\end{array}$ \\
\hline 2 & Air purification systems & $\begin{array}{l}\text { Legionella: Bioactive nano- } \\
\text { filters }\end{array}$ & $\begin{array}{l}\text { Rodrigues, et al. } \\
(2011)[43]\end{array}$ \\
\hline 3 & Air Treatment Filters & Ag-TiO2 Nanorod & $\begin{array}{l}\text { Wang, S. J. et al. } \\
(2020)[44]\end{array}$ \\
\hline 4 & Oodour adsorbent nanofilters & $\begin{array}{l}\text { cyclodextrin molecules into } \\
\text { electrospun cellulose acetate } \\
\text { webs }\end{array}$ & $\begin{array}{l}\text { Ghorani, B. et al. } \\
\text { (2019) [45] }\end{array}$ \\
\hline 5 & $\begin{array}{l}\text { Air purification and self- } \\
\text { cleaning }\end{array}$ & Photocatalytic nanomaterials & $\begin{array}{l}\text { Rafique, M. S., et al. } \\
(2020)[46]\end{array}$ \\
\hline 6 & $\begin{array}{l}\text { Effective air purifier to } \\
\text { remove PM and to reduce } \\
\text { NO from automobile exhaust }\end{array}$ & Nickel nanofiber & $\begin{array}{l}\text { Tang, X. et al. (2020). } \\
\text { [47] }\end{array}$ \\
\hline 7 & $\begin{array}{l}\text { Poly (Vinyl Alcohol) } \\
\text { Nanofilters }\end{array}$ & $\begin{array}{l}\text { Photocatalytic Property of } \\
\text { Titanium Dioxide }\end{array}$ & $\begin{array}{l}\text { Yeo, J. H. et al. } \\
(2020) .[48]\end{array}$ \\
\hline 8 & $\begin{array}{l}\text { Hepatitis E virus elimination } \\
\text { filter }\end{array}$ & Plasma based Fibrinogen & $\begin{array}{l}\text { Yunoki, M. et al } \\
\text { (2008). [49] }\end{array}$ \\
\hline 9 & Virus removing Nano filters & $\begin{array}{l}\text { Carbon nanotube-silver } \\
\text { composites }\end{array}$ & $\begin{array}{l}\text { Kim, J. P., (2016). } \\
{[50]}\end{array}$ \\
\hline 10 & $\begin{array}{l}\text { Bacteria Removing Nano } \\
\text { filters }\end{array}$ & Graphene oxide nanomaterials & $\begin{array}{l}\text { Ruiz, O. N. et al. } \\
(2015) .[51]\end{array}$ \\
\hline 11 & $\begin{array}{l}\text { Separate SF6 gas from a } \\
\text { mixture of gases SF6 + N2 }\end{array}$ & $\begin{array}{l}\text { Ion irradiated } \\
\text { Polyethyleneterephthalate } \\
\text { (PET) film as nanofilters }\end{array}$ & $\begin{array}{l}\text { Vijay, Y. K. et al. } \\
\text { (2009). [52] }\end{array}$ \\
\hline
\end{tabular}




\begin{tabular}{|l|l|l|l|}
\hline 12 & $\begin{array}{l}\text { Nanofibrous filter with low } \\
\text { air resistance for high- } \\
\text { efficiency filtration of } \\
\text { particulate matter }\end{array}$ & $\begin{array}{l}\text { Electrospun poly (vinyl } \\
\text { alcohol)/cellulose nanocrystals } \\
\text { composite }\end{array}$ & $\begin{array}{l}\text { Zhang, Q. et al. } \\
\text { (2019). [53] }\end{array}$ \\
\hline 13 & Air purification & $\begin{array}{l}\text { Titanium carbide Ti3C2Tx } \\
\text { (MXene) enhanced PAN } \\
\text { nanofiber membrane }\end{array}$ & $\begin{array}{l}\text { Gao, X. et al. (2019). } \\
\text { [54] }\end{array}$ \\
\hline
\end{tabular}

\section{DESIGN A MEGA MACHINE DEVICE CONSISTING OF NANOTECHNOLOGY BASED CASCADED FILTERS TO CLEAN POLLUTED AIR:}

Based on the research results published in the area of nanotechnology, now it is possible to remove many hazardous pollutants from polluted air. Hence it is possible to design and develop an air cleaner both for indoor and outdoor, for small scale and large scale cleaning purposes respectively. To remove many polluted constituents that are mixed in the air, a cascaded filters principle can be used. A cascaded design based nanotechnology filters can give additive effects while purifying input pollute air as clean air at the output. A cascaded mega air-cleaner machine consists of many filters made of different nanomaterials to filter different components of polluted air, cascaded serially with the airflow direction.

The design is based on the imagination of an ideal environment cleaner with $100 \%$ efficiency as shown in Figure 1 where, the system with ideal fan as the first stage takes impure air of any impurity level as input and by passing it through many nanotechnology supported filter stages of different characteristics, the clean air without any impurity is taken at the output. The system uses an ideal Fan or ideal Pump as the first stage which is driven by a perfectly renewable energy source. The energy source called ideal energy source [55] considered in an ideal air purifier is analogous to the one used in an ideal water purifier [56].

By keeping the ideal air purifier machine shown in figure 1 as a reference, we have discussed the design of a practical air cleaning machine for outdoor air cleaning called mega machine [2] consisting of four stages of filtering systems using nanotechnology-based filtering membranes. The machine is driven by solar energy or wind energy supported high speed fan to pump the polluted air from indoor or outdoor into the machine. Depending on the capacity of this solar pumped fan, the impure air from open space is pushed to cascaded filters to purify the air in different stages and finally, the pure air free from all impurities pushed out from the machine. The filtering stages are designed using different varieties of nanotechnology membranes as per the information listed in table 3. The block diagram of Practical Air Cleaning Machine using Nanotechnology is shown in figure 2. The various stages are :

(1) Renewable/Solar Energy based Fan: A big fan is used to suck the impure air from a polluted place. The fan being the first component forces polluted air towards a series of nano-filter stages at high speed. This highspeed fan is driven by continuous electric power generated either a solar energy power plant or wind energy power plant as a renewable energy source.

(2) Nanofilter Stage for Particulate matter: The first stage of mega filter is designed to remove and separate all particulate matters which are considered as serious threats to public health. Suspended particulate matter consists of a mixture of particles and droplets in the air of both organic and inorganic particles such as dust, soil, acids, metals, nitrates, smoke, soot, and liquid droplets. The particulate matter particles vary in size, composition, and origin. The particulate matter particles of size between $100 \mathrm{~nm}$ to $2.5 \mu \mathrm{m}$ are called fine fraction and above size $2.5 \mu \mathrm{m}$ are called coarse particles. The particulate matter particles of size below $100 \mathrm{~nm}$ are called ultrafine particles and are accounted for over $90 \%$ of the numbers. Various techniques are used to separate these particulates which include mechanical filtration, electrostatic filtration, and nanofibers. Mechanical filtration includes mechanical collectors like dust cyclones, multi-cyclones, etc., electrostatic filtration includes electrostatic precipitators and particulate scrubbers. The nanofilter stage is made up of nanofibers of natural proteins, electrostatic polyesters composed of conductive nanowires, etc.

\section{(3) Nanofilter Stage for VOC:}

The second stage of mega filter is designed to remove and separate all volatile organic compounds 
(VOCs) which are also considered as serious threats to public health [57]. Various techniques used for VOC removal include Thermal oxidizers, Adsorption using activated carbon, Cryogenic condensers, Biofilters, etc. Photocatalysis that utilizes semiconductor nanoparticles can decompose VOCs in gaseous pollutants directly into harmless $\mathrm{CO}_{2}$ and $\mathrm{H}_{2} \mathrm{O}$ under ambient conditions. The principles of photocatalytic degradation of VOCs using visible light and photocatalyst deactivation of VOCs can be used in this stage. Various metal nanoparticles can be used for the degradation of VOCs. This include :

(i) Metallic nickel nanoparticles were employed as catalysts for the thermal decomposition of methane to produce hydrogen.

(ii) Nanosilver-decorated titanium dioxide $\left(\mathrm{TiO}_{2}\right)$ nanofibers can be used to remove Nitrogen oxide (NOx), volatile organic compounds (VOCs), microbial activity.

(iii) Titanium dioxide nanoparticles (TNPs) can be used for photocatalytic degradation of ethylene which is a VOC.

(iv) Air filtration technology using antimicrobial materials such as silver nanoparticles, copper nanoparticles, CNTs, and natural products is considered the most applied and effective technique to remove bioaerosols through ventilation processes.

(v) Electrospun nanofibers (NF) (hydroxypropyl-beta-cyclodextrin (HP $\beta C D$ ), NF, and hydroxypropyl-gammacyclodextrin ( $\mathrm{HP} \gamma \mathrm{CD}) \mathrm{NF}$ ) for entrapping VOCs like aniline and benzene.

(vi) Nanometalic decorated $\mathrm{TiO}_{2}$ can be used for the degradation of biological substances, such as viruses, bacteria, parasites, and antibiotics.

\section{(4) Nanofilter Stage for Toxic Gases:}

The third stage of mega machine is designed to remove and separate all toxic gases present in polluted incoming air which are also considered as serious threats to public health. Toxic gases like $\mathrm{NO}_{2}$, Ozone, $\mathrm{SO}_{2}, \mathrm{CO}, \mathrm{CO}_{2}$, $\mathrm{CH} 4, \mathrm{CS}_{2}, \mathrm{NH}_{3}$, etc. This include :

(i) Titanate nanotubes (TNTs) and their derivatives have been widely reported for the photocatalytic oxidation of NOx.

(ii) Modified $\mathrm{TiO}_{2}$ with different loads of silver was used for the photocatalytic decomposition of $\left(\mathrm{N}_{2} \mathrm{O}\right)$ to nitrogen and oxygen.

(iii) $\mathrm{SO}_{2}$ adsorption is possible on the surface of $\mathrm{COFe}_{2} \mathrm{O}_{4}$ magnetic nanoparticles.

(iv) Horn-shaped carbon nanotubes can be used to remove Carbon dioxide $\left(\mathrm{CO}_{2}\right)$, methane $\left(\mathrm{CH}_{4}\right)$, carbon monoxide (CO), and nitrogen $\left(\mathrm{N}_{2}\right)$.

(v) Single-walled carbon nanotubes can be used to remove Nitrogen $\left(\mathrm{N}_{2}\right)$, methane $\left(\mathrm{CH}_{4}\right)$, carbon monoxide (CO), carbon dioxide $\left(\mathrm{CO}_{2}\right)$.

(vi) Zinc oxide and zirconium hydroxide nanoparticles can be used to remove Nitrogen oxide $\left(\mathrm{NO}_{2}\right)$, sulfur oxides $\left(\mathrm{SO}_{2}\right)$.

(vii) Aligned carbon nanotubes can be used for filtering Aerosols.

(viii) Ag/SBA-15 nanocomposites can be used to filter Carbon monoxide (CO).

(ix) $\mathrm{Zn}_{2} \mathrm{O}_{12}$ nanocage can be used to adsorb Carbon disulfide $\left(\mathrm{CS}_{2}\right)$.

(x) Silica nanoparticle (SiNPs) can be used to capture Atmospheric lead $(\mathrm{Pb})$.

(xi) Ruthenium nanoparticle catalysts $\left(\mathrm{Ru} / \gamma-\mathrm{Al}_{2} \mathrm{O}_{3}\right)$ can be used to decompose Nitrogen oxide $\left(\mathrm{N}_{2} \mathrm{O}\right)$.

(xii) $\mathrm{Mg}$ ferrite nanospheres $\left(\mathrm{MgFe}_{2} \mathrm{O}_{4}\right)$ and Titanium dioxide nanoparticles (TNPs) can be used to adsorb Sulfur dioxide $\left(\mathrm{SO}_{2}\right)$.

\section{(5) Nanooxygenator:}

Nanooxygenator emits oxygen through various chemical processes by converting $\mathrm{CO}_{\mathrm{x}}, \mathrm{NO}_{\mathrm{x}}, \mathrm{SO}_{\mathrm{x}}$, etc. into pure oxygen and hence increases oxygen contents in outgoing purified air. 


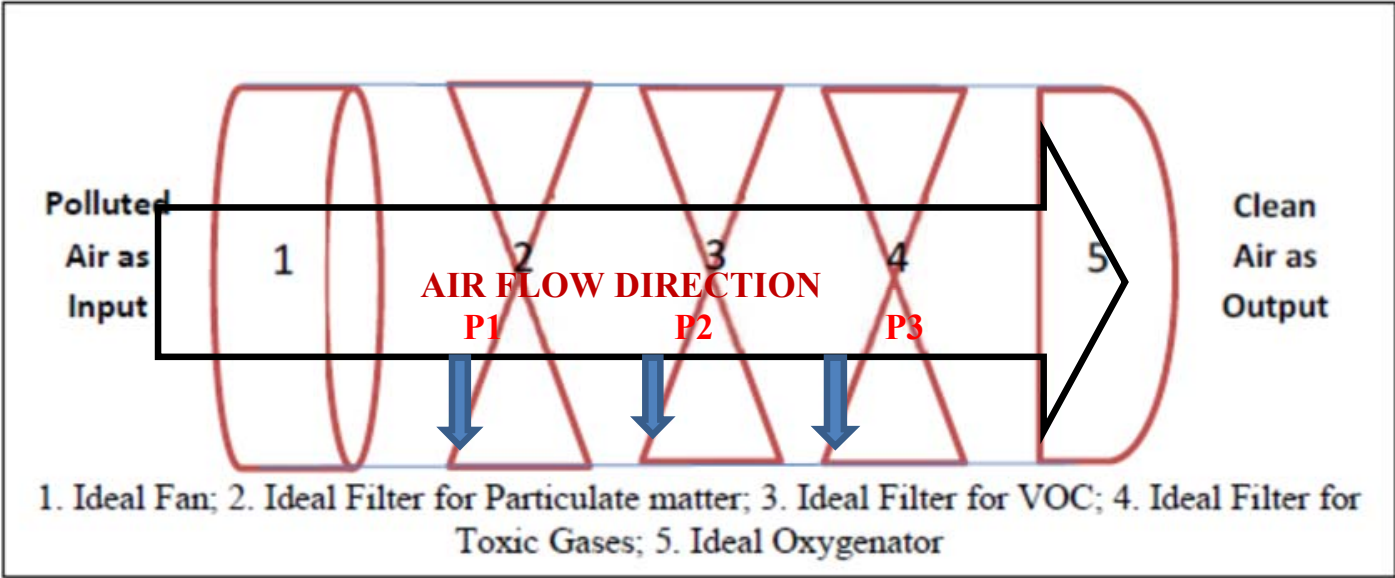

Fig. 1: Block diagram of Ideal Environment Cleaner [2]

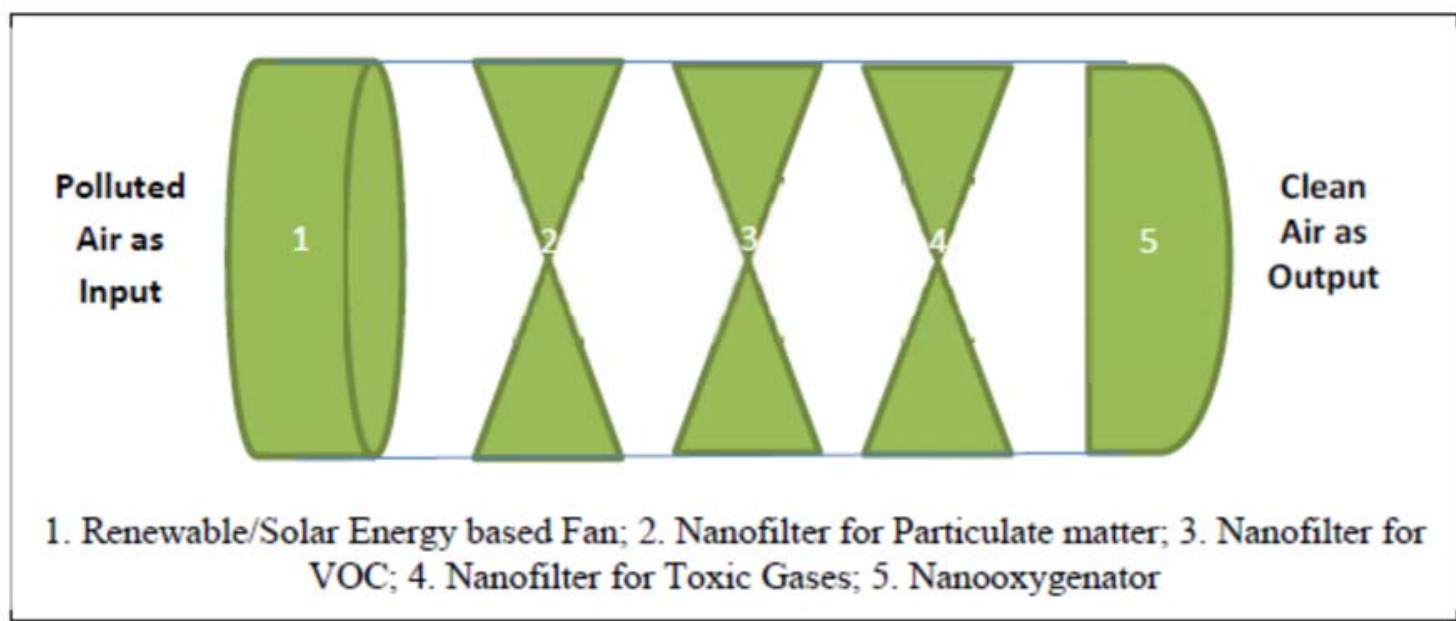

Fig. 2: Block diagram of Practical Air Cleaning Machine using Nanotechnology [2]

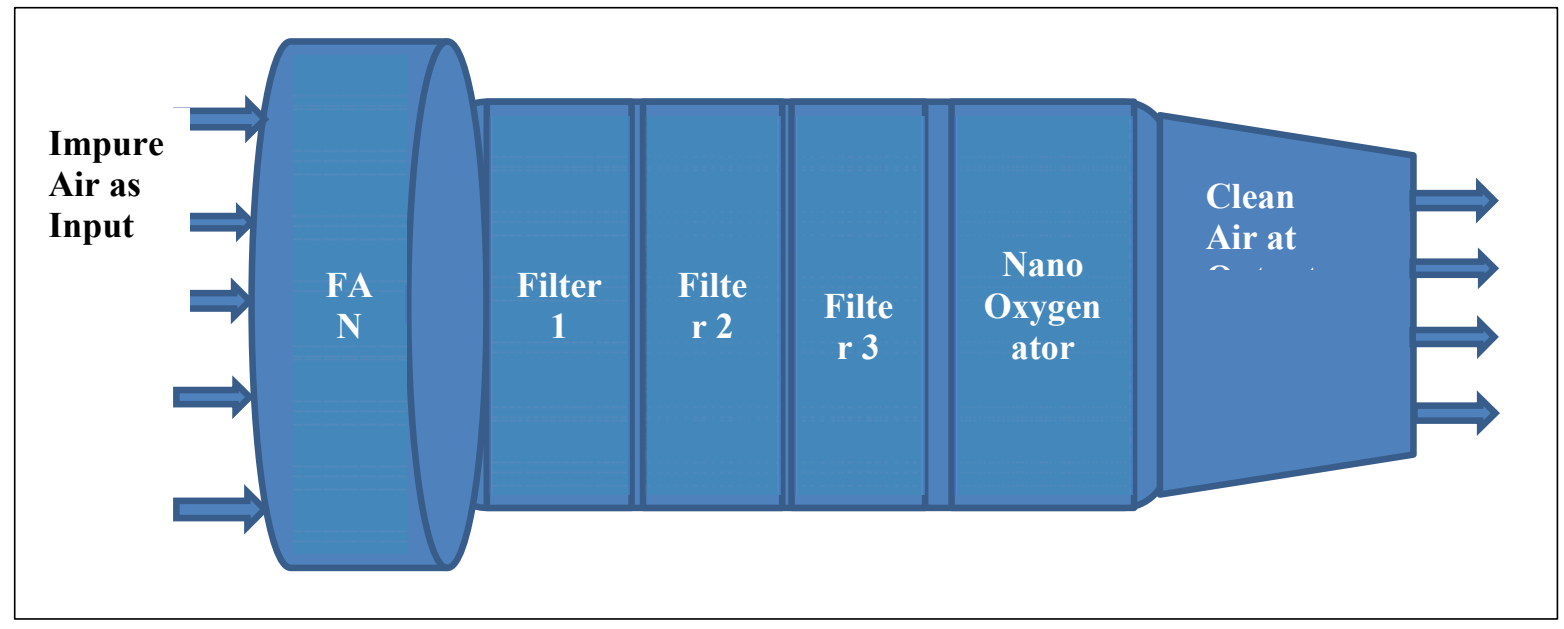

Fig. 3: Structural Design of Mega Air Cleaning Machine

The mega machine can be scalable to different sizes and different capacities by increasing the capacity of the air inhaling pump and the size of the other four stages of air filtration. The structural design of the proposed 
mega air cleaner machine is visualized in figure 3. This mega machine can be made long by maintaining a considerably long distance between each stage in a long pipe kind of structure for avoiding the mix of output cleaned air with input polluted air. Depending upon the necessity of air quality requirements of a given place, both the size and number of these mega air cleaning machines can be increased or vice-versa.

\section{PROSPECTS OF THE AIR CLEANING MEGA MACHINES:}

\subsection{World-wide Requirement:}

The nanotechnology based mega air cleaning machine is an immediate requirement for both indoor and outdoor air cleaning and pollution control. Based on the current exceptionally high air pollution index measured in different places of the countries and depicted in table 1, an immediate and compulsory decision is required by country governments worldwide to develop and install many such systems for controlling the pollution.

\subsection{Combating with Health Hazardous Pollutants:}

It is found that the components in the polluted air contain toxic gases, volatile organic compounds (VOCs), particulates, and various microorganisms like viruses, bacteria, parasites, and antibiotics which are considered serious threats to public health. Combating with such health hazardous issues and finding an acceptable solution at least to decrease the effects of these pollutants on the life of living beings is an immediate requirement to maintain a sustainable and supportive climate around the earth.

\subsection{Seamless Industrialization:}

In the process of improving comfortability in human lifestyle by using technology, the process of industrialization is spread in primary, secondary, tertiary, and quaternary sectors. However, this seamless industrialization has led to the growth of many manufacturing industries and the associated waste generated by them. Part of this waste along with various byproducts contributing to the environment as pollutants. Hence seamless industrialization without effective precaution on pollution control is a major cause of air and water pollution.

\subsection{Accelerated development:}

While there are many advantages of the rapid development of cities, often unplanned urbanization brings risks of profound social instability, resource crises, and potential for devastating spread of disease due to environmental pollution. A systematic plan and its implementation of controlling pollution are essential in every city.

\subsection{To achieve Sustainable Development Goals (SDGs):}

The development and installation of mega air cleaners based on suitable technology to control air pollution is essential all over the world to realize the five out of seventeen United Nations Sustainable Development Goals (SDGs) which include (1) Ensuring healthy lives and wellbeing for all at all ages by means of the pollution free atmosphere (Goal 3), (2) To ensure availability and sustainable management of potable water and sanitation for all by controlling all kind of pollution which degrade potable water (Goal 6), (3) To build resilient infrastructure, promote inclusive and sustainable industrialization and foster innovation by controlling industrial pollution (Goal 9), (4) To make cities and human settlements inclusive, safe, resilient, and sustainable by controlling the pollution in the cities (Goal 11), and (5) To take urgent action to combat climate change and its impact by means of controlling all type of pollutions and environmental degradation (Goal 13). Thus, urgent action on developing, manufacturing, and installing such high speed, mega air cleaner at considerably low cost should be a priority for all countries.

\subsection{Enhanced Human life-span:}

By controlling the toxic, VOC, and hazardous microorganism pollutants in the atmospheric air in a large quantity using renewable natural resources like solar and wind energy, it is possible to maintain satisfactory health for living beings. Alternately, it is possible to control many health-related human diseases leading to life span enhancement at least for a few years with a healthy and comfortable life.

\subsection{Sustainable climate for Future Generations:}


In the name of growing civilization and economic development, countries are harnessing the environment in an unhealthy way. The aim of sustainable development is to balance the economic, environmental, and social needs to allow prosperity for present and future generations. This includes social progress through equality, environmental protection, and stable economical and technological growth. Protecting the environment by means of decreasing pollution is the need of the hour and the responsibility of every country for gifting a safe and livable environment for future generations.

\section{CHALLENGES OF AIR CLEANING MEGA MACHINES:}

\subsection{Challenges of Design:}

The design of mega air cleaner using nanotechnology contains a systematic plan and specification for construction of the system in the most effective manner to fulfill the planned objectives. The design of mega air cleaner should have various parts called stages to suck the polluted air in large quantity from the atmosphere and force it toward various stages of cleaning. As per the current industry standard, a big and strong fan called a rotor is suitable for this purpose and is the first stage of the device. To make this stage continuously functioning huge and continuous electric power should be supplied to the stage. Using electric power generated by a renewable energy source like a mega solar plant and energy storage facility or wind energy plant the device can be powered continuously for unstopped functioning. Depending on the size and strength of sir sucking,

The second stage should focus on filtering all particulate matters from micro size to nano size. By designing different pore size filters these particles can be separated and collected at the bottom of the system. Care should be taken to avoid the mix of these particulate matters to the next stages of air cleaning. The polluted air which is free from particulate matter will enter the next stage called the second stage. If required some structural design can be modified to provide another fan between the second and third stages to speed up the cleaning process in the third stage.

The third stage should be designed to remove and separate all volatile organic compounds (VOCs) and hazardous microorganism pollutants which are also considered serious threats to public health. Nanosystems working based on photocatalytic deactivation, adsorption, and nanofiltration of pollutants. The cleaned air free from VOC and microorganisms will enter the next stage called the fourth stage. The pollutants collected in this stage should be handled properly to avoid the mix of them with the next level.

The fourth stage is the nano-filter for toxic gases and should include a series of components to remove all toxic gases present in the incoming air. The efficiency of this stage can be increased by providing an internal fan to force the filtered air from stage 3 to stage 4 . Stage 4 contains the nanotechnology components designed to filter toxic gases like $\mathrm{NO}_{2}$, Ozone, $\mathrm{SO}_{2}, \mathrm{CO}, \mathrm{CO}_{2}, \mathrm{CH}_{4}, \mathrm{CS}_{2}, \mathrm{NH}_{3}$, etc. The output of stage 4 will be pure air free from all pollutants. Here we can add an additional stage to enrich the oxygen ratio of pure air by adding a nanotechnology based oxygenator. The oxygenator collects toxic gases from the fourth stage and converts them into oxygen and adds the resultant oxygen to cleaned air at the output. Thus, the designed mega air cleaner collects polluted air and converts it into pure and oxygen-rich air without using any external stimulation. This design of air cleaner is fully sustainable design and except for periodic nanomaterial based filter replacement, is completely self-sufficient in all aspects and capable to clean the air continuously for years together.

\subsection{Challenges of Construction:}

The construction of nanotechnology based air cleaning mega machine is more challenging in terms of cost, time, and availability of raw materials. Construction of particulate removal stage, VOC and micro-organisms removal stage, and toxic gases removal stage are complex and tedious. Construction of oxygenator by converting toxic gases into oxygen through proper chemical reactions is also a complex and costly process initially for a few years until the nanotechnology reaches its saturation stage. The technology of supporting stages like solar or wind powered fans are reached an almost saturation stage and manageable with comparatively low investment.

\subsection{Challenges of Maintenance:}

Proper maintenance of mega cleaning machines installed in outdoor industrial locations as well as in the cities is essential as the filters may get blocked periodically. Many times, the maintenance of the nano-filter stages needs total replacement of nanomembranes which may be a costly, complicated, and tedious process.

\subsection{Challenges of handling by-products:}


The toxic items separated and the by-products produced during the air cleaning process should be handled with proper care. Otherwise, they may further mix with atmospheric air and end up polluting the air further. The mega machine proposed here is a self-manageable system where many byproducts are recycled to produce pure oxygen in nano-oxygenator stage.

By means of a suitable commercialization model, these nanotechnologies based mega air cleaner machines can be marketed after systematic development [58-61]. The engineering aspects of the production process of such mega cleaner is under development and will be patented soon. The commercialization process involves marketing the machine for various countries through the world environment consortium and installing such machines in mega-cities and industrial areas to promote a pollution free environment for the future generation and is considered as an essential and urgent requirement.

\section{ABCD ANALYSIS FROM VARIOUS STAKEHOLDERS POINT OF VIEWS:}

In this section, the nanotechnology based air cleaning mega machine is analyzed using a system analysis method called ABCD analysis framework developed by Aithal et al [62-80]. Table 5 lists the advantages, benefits, constraints, and disadvantages of mega air cleaning machines using nanotechnology, and Table 6 lists the advantages, benefits, constraints, and disadvantages of mega air cleaning machines using nanotechnology $\mathrm{ABCD}$ Analysis from various Stakeholders point of view. ABCD analysis shows that the advantages and benefits of these machines are overtaking the constraints and disadvantages, leading to the practicality of the usage.

Table 5 : ABCD listings of proposed Mega Air Cleaner Machine [2]

\begin{tabular}{|c|c|c|}
\hline S. No. & Constructs & Affecting Factors \\
\hline 1 & Advantages & $\begin{array}{l}\text { (1) Optimum cleaning of all the four types of impurities are possible } \\
\text { (2) Uses renewable energy (either solar or wind) } \\
\text { (3) Scalable system } \\
\text { (4) Low cost system for large scale deployment } \\
\text { (5) Simple cascade design } \\
\text { (6) Oxygenator stage monitors the oxygen level in output air } \\
\text { (7) Large volume of air can be cleaned every day } \\
\text { (8) Can be used both indoor and outdoor } \\
\text { (9) Each filter stage separates the respective impurities as by-products }\end{array}$ \\
\hline 2 & Benefits & $\begin{array}{l}\text { (1) Continuous output of Clean air decreases the pollution } \\
\text { (2) Renewable energy leads to less pollution } \\
\text { (3) Scalability leads to optimum usage in different locations } \\
\text { (4) Least maintenance cost if deployed in large scale } \\
\text { (5) Cascade design o provides customization } \\
\text { (6) Maintenance of optimum oxygen level in the surroundings due to } \\
\text { continuous circulation of air in the machine } \\
\text { (7) Air pollution can be drastically reduced } \\
\text { (8) Air pollution can be stopped at its starting stage } \\
\text { (9) The by-products generated at each stage can be utilized effectively }\end{array}$ \\
\hline 3 & Constraints & $\begin{array}{l}\text { (1) Nanofiltration membranes are an expensive part of the process } \\
\text { (2) Periodic maintenance is required to clean filter membranes } \\
\text { (3) Use of solar energy hinder the mobility of the system }\end{array}$ \\
\hline 4 & Disadvantages & $\begin{array}{l}\text { (1) Comparatively high initial investment is required. } \\
\text { (2) Periodic maintenance cost adds to the total cost } \\
\text { (3) Machine is fixed at a given location due to its immobility which is } \\
\text { due to the use of renewable energy }\end{array}$ \\
\hline
\end{tabular}


Table 6 : ABCD Analysis of installing mega air cleaner from various Stakeholders point of view

\begin{tabular}{|c|c|c|c|c|c|c|}
\hline $\begin{array}{l}\text { S. } \\
\text { No }\end{array}$ & $\begin{array}{l}\text { Determina } \\
\text { nt Issue }\end{array}$ & $\begin{array}{c}\text { Key } \\
\text { Attributes }\end{array}$ & $\begin{array}{c}\text { Advantage } \\
s\end{array}$ & Benefits & Constraints & $\begin{array}{c}\text { Disadvanta } \\
\text { ges }\end{array}$ \\
\hline \multirow[t]{3}{*}{1} & \multirow[t]{3}{*}{ Country } & Air Quality & $\begin{array}{l}\text { Pollution } \\
\text { control }\end{array}$ & $\begin{array}{l}\text { Clean } \\
\text { environment }\end{array}$ & $\begin{array}{l}\text { Political \& } \\
\text { Bureaucratic } \\
\text { mindset }\end{array}$ & $\begin{array}{l}\text { Maintenance } \\
\text { to manage } \\
\text { the quality }\end{array}$ \\
\hline & & Cost & $\begin{array}{l}\text { Low cost at } \\
\text { high } \\
\text { volume }\end{array}$ & $\begin{array}{l}\text { Clean air and } \\
\text { remedy for } \\
\text { pollution }\end{array}$ & $\begin{array}{l}\text { Mass production } \\
\text { in every country }\end{array}$ & $\begin{array}{l}\text { Initial } \\
\text { investment }\end{array}$ \\
\hline & & Health & $\begin{array}{l}\text { Decreased } \\
\text { air } \\
\text { pollution }\end{array}$ & $\begin{array}{l}\text { Improved } \\
\text { health } \\
\text { condition of } \\
\text { citizens }\end{array}$ & $\begin{array}{l}\text { Installing } \\
\text { required number } \\
\text { of machines }\end{array}$ & - \\
\hline \multirow[t]{3}{*}{2} & \multirow[t]{3}{*}{ Companies } & Air Quality & $\begin{array}{l}\text { Emission } \\
\text { control }\end{array}$ & $\begin{array}{l}\text { Clean } \\
\text { environment }\end{array}$ & $\begin{array}{l}\text { Deciding the } \\
\text { number of } \\
\text { machines to be } \\
\text { installed in their } \\
\text { premises }\end{array}$ & $\begin{array}{l}\text { Maintenance } \\
\text { of sir quality }\end{array}$ \\
\hline & & Cost & $\begin{array}{l}\text { Govt } \\
\text { support and } \\
\text { subsidy }\end{array}$ & $\begin{array}{l}\text { Tax Benefits } \\
\text { and Green } \\
\text { business }\end{array}$ & $\begin{array}{l}\text { Investment for } \\
\text { installation }\end{array}$ & $\begin{array}{l}\text { Maintenance } \\
\text { cost }\end{array}$ \\
\hline & & Health & $\begin{array}{l}\text { Environme } \\
\mathrm{nt} \\
\text { friendliness }\end{array}$ & $\begin{array}{l}\text { Better } \\
\text { employees } \\
\text { health }\end{array}$ & $\begin{array}{l}\text { Systematic } \\
\text { disposal of by- } \\
\text { products }\end{array}$ & - \\
\hline \multirow[t]{2}{*}{3} & \multirow[t]{2}{*}{ Citizens } & Air Quality & $\begin{array}{l}\text { Clean \& } \\
\text { oxygen } \\
\text { enriched air }\end{array}$ & $\begin{array}{l}\text { Clean and } \\
\text { pollution free } \\
\text { environment }\end{array}$ & $\begin{array}{l}\text { Anticipated } \\
\text { nanotechnology } \\
\text { based side } \\
\text { effects }\end{array}$ & - \\
\hline & & Health & $\begin{array}{l}\text { Pollution } \\
\text { free air }\end{array}$ & $\begin{array}{l}\text { No pollution } \\
\text { based health } \\
\text { hazards }\end{array}$ & $\begin{array}{l}\text { Worry on } \\
\text { disposal of } \\
\text { byproducts }\end{array}$ & - \\
\hline \multirow[t]{2}{*}{4} & \multirow[t]{2}{*}{ Society } & Air Quality & $\begin{array}{l}\text { Pollution } \\
\text { less } \\
\text { environmen } \\
t\end{array}$ & $\begin{array}{l}\text { Clean and } \\
\text { green } \\
\text { environment }\end{array}$ & $\begin{array}{l}\text { Deciding the } \\
\text { number of } \\
\text { machines to be } \\
\text { installed due to } \\
\text { variation in air } \\
\text { quality }\end{array}$ & - \\
\hline & & Health & $\begin{array}{l}\text { Low } \\
\text { pollution } \\
\text { content in } \\
\text { air }\end{array}$ & $\begin{array}{l}\text { Decreased } \\
\text { pollution } \\
\text { based health } \\
\text { hazards }\end{array}$ & $\begin{array}{l}\text { Managing the } \\
\text { byproducts }\end{array}$ & $\begin{array}{l}\text { Anticipated } \\
\text { new } \\
\text { problems if } \\
\text { improper } \\
\text { management } \\
\text { of by } \\
\text { products }\end{array}$ \\
\hline
\end{tabular}

\section{SUGGESTIONS:}

(1) The proposed nanotechnology-based air cleaning mega machine can be used both for indoor and outdoor applications by making suitable modifications in the design structure.

(2) The mega machine of different sizes \& capacities can be used in identified locations using traditional 
electricity also without developing solar or wind energy infrastructure.

(3) By varying the length of the mega machine suitably, it is possible to avoid the mix of output cleaned air with input polluted air.

(4) Variable size and capacity machines can be installed at industry locations, cities, and other places based on the pollution level of the location.

(5) Proper periodical maintenance of the machine is required to get reliable efficiency.

(6) The cleaning stages can be altered depending on the density of constituents to be separated in input pollutant air.

(7) Development and installation of mega air cleaner can be further analyzed country specific by means of CostBenefit Analysis [81].

(8) The nanotechnology-based air cleaner can be customized for individual industry requirements and accordingly the number of stages and substages of filtering can be decided.

(9) The oxygenator stage must be compulsory for mega machines installed in cities whereas they can be optional for industrial areas.

(10) United Nations member countries should involve in the commercialization of the machine for large scale usage.

\section{CONCLUSION:}

It is known that environmental pollution is the byproducts of industrialization and civilization. For leading a comfortable and happy life for human beings, industrialization, and civilization using advanced technology is essential. The control of environmental pollution or a reverse operation to decrease pollution is essential to avoid any disasters for living a peaceful life on mother earth. Advancement in technology has not only provided more opportunity to pollute the environment but also provided the ability to control it. By utilizing, the recently identified universal technologies which include Nanotechnology for innovating real processes and ICCT for innovating intelligent machines and virtual processes [82-87], human beings can control bad things and initiate good things for human prosperity. Maintaining free resources like air, water, and food given by mother earth for our future generations is our responsibility and is possible only by using suitable technology. In this paper, we have disclosed and analyzed an idea and design on how to use nanotechnology effectively to solve our long existing man-made problem of reversing the polluted environment for further use by present and future generations. This mega air cleaner can be also a boon to the living beings of society to maintain good health for long period and hence priority should be given to realize by providing financial support by country governments/World Bank or United Nations Organization immediately.

\section{REFERENCES :}

[1] Shubhrajyotsna Aithal (2019). Principles of Environmental Studies. Srinivas Publication. pp. 06-21, DOI: http://doi.org/10.5282/zenono.2528598.

[2] Shubhrajyotsna Aithal \& Aithal, P. S. (August 2020). Cleaning the Environment using Nanotechnology - A Review based Mega-Machine Design. In "Environmental Information Sciences: With aspects on Allied Areas \& other emerging interdisciplinary Environmental Concerns" edited by P.K. Paul et al. published by New Delhi Publishers, New Delhi, India, pp. 13-40. ISBN: 978-93-88879-91-0. DOI: https://doi.org/10.5281/zenodo.4243767

[3] Kampa, M., \& Castanas, E. (2008). Human health effects of air pollution. Environmental pollution, 151(2), 362-367.

[4] Ferrer-i-Carbonell, A., \& Gowdy, J. M. (2007). Environmental degradation and happiness. Ecological economics, 60(3), 509-516.

[5] Aithal, P. S., \& Aithal, S. (2020). Conceptual Analysis on Higher Education Strategies for various TechGenerations. International Journal of Management, Technology, and Social Sciences (IJMTS), 5(1), 335351.

[6] Aithal, P. S., \& Aithal, S. (2015). A review on Anticipated Breakthrough Technologies of 21st Century. International Journal of Research \& Development in Technology and Management ScienceKailash, 21(6), 112-133. 
[7] Aithal, P. S., \& Aithal, S. (2016). Nanotechnology innovations and commercialization-opportunities, challenges \& reasons for delay. International Journal of Engineering and Manufacturing (IJEM), 6(6), 1525.

[8] Aithal, P. S. (2016). Nanotechnology Innovations \& Business Opportunities: A Review. International Journal of Management, IT and Engineering, 6(1), 182-204.

[9] Aithal, P. S., \& Aithal, S. (2016). A New Model for Commercialization of Nanotechnology Products and Services. International Journal of Computational Research and Development, 1(1), 84-93.

[10] Aithal, S., \& Aithal, P. S. (2018). Concept of Ideal Water Purifier System to Produce Potable Water and its Realization Opportunities using Nanotechnology. International Journal of Applied Engineering and Management Letters (IJAEML), 2(2), 8-26.

[11] Aithal, P. S., \& Aithal, S. (2016). Nanotechnology Innovations \& Business Opportunities in Renewable Energy Sector. International Journal of Engineering Research and Modern Education (IJERME), 1(1), 674-692.

[12] Aithal, P. S., \& Aithal, S. (2016). Nanotechnological innovations \& business environment for Indian automobile sector: a futuristic approach. International Journal of Scientific Research and Modern Education (IJSRME), 1(1), 296-30.

[13] Aithal, A., \& Aithal, P. S. (2018). The Concept of Ideal Drug \& Its Realization Opportunity Using present Pharmaceutical Sciences Scenario. International Journal of Health Sciences and Pharmacy (IJHSP), 2(2), $11-26$.

[14] Aithal, P. S., \& Aithal, S. (2016). Opportunities \& Challenges for Green Technology in 21st Century. International Journal of Current Research and Modern Education (IJCRME), 1(1), 818-828.

[15] Aithal, P. S., \& Aithal, S. (2018). Factor \& Elemental Analysis of Nanotechnology as Green Technology using ABCD Framework. International Journal of Management, Technology, and Social Sciences (IJMTS), 3(2), 57-72.

[16] Aithal, P. S., \& Aithal, S. (2015). Ideal Technology Concept \& its Realization Opportunity using Nanotechnology. International Journal of Application or Innovation in Engineering \& Management (IJAIEM), 4(2), 153-164.

[17] Aithal, P. S., \& Aithal, S. (2019). Strategic Management of Universal Technologies for Redefining Productivity \& Performance. International Journal of Applied Engineering and Management Letters (IJAEML), 3(2), 81-95.

[18] Aithal, P. S., \& Aithal, S. (2018). Study of various General-Purpose Technologies and Their Comparison towards developing Sustainable Society. International Journal of Management, Technology, and Social Sciences (IJMTS), 3(2), 16-33.

[19] Rickerby, D. G., \& Morrison, M. (2007). Nanotechnology and the environment: A European perspective. Science and Technology of Advanced Materials, 8(1-2), 19-23.

[20] Muller, C. O., Yu, H., \& Zhu, B. (2015). Ambient air quality in China: the impact of particulate and gaseous pollutants on IAQ. Procedia Engineering, 121, 582-589.

[21] Yunus, I. S., Harwin, Kurniawan, A., Adityawarman, D., \& Indarto, A. (2012). Nanotechnologies in water and air pollution treatment. Environmental Technology Reviews, 1(1), 136-148.

[22] Amade, R., Hussain, S., Ocaña, I. R., \& Bertran, E. (2014). Growth and functionalization of carbon nanotubes on quartz filter for environmental applications. J. Environ. Eng. Ecol. Sci, 3(2), 1-7.

[23] Singh, S. B. and Tandon, P. K. (2014). Catalysis: A brief review on nano-catalyst. JECE. 2(1), 106-115.

[24] Balamurugan, R., Sundarrajan, S., \& Ramakrishna, S. (2011). Recent trends in nanofibrous membranes and their suitability for air and water filtrations. Membranes, 1(3), 232-248. 
[25] Xu, J., Liu, C., Hsu, P. C., Liu, K., Zhang, R., Liu, Y., \& Cui, Y. (2016). Roll-to-roll transfer of electrospun nanofiber film for high-efficiency transparent air filter. Nano letters, 16(2), 1270-1275.

[26] Mohamed, E. F. (2017). Nanotechnology: future of environmental air pollution control. Environmental Management and Sustainable Development, 6(2), 429-454.

[27] Ibrahim, R. K., Hayyan, M., AlSaadi, M. A., Hayyan, A., \& Ibrahim, S. (2016). Environmental application of nanotechnology: air, soil, and water. Environmental Science and Pollution Research, 23(14), 1375413788 .

[28] Kharat, M. G., Murthy, S., \& Kamble, S. J. (2017). Environmental Applications of Nanotechnology: A Review. ADBU Journal of Engineering Technology, 6(3), 1-11.

[29] Zhao, W., Chen, I. W., \& Huang, F. (2019). Toward large-scale water treatment using nanomaterials. Nano Today, 27, 11-27.

[30] Shubrajyotsna Aithal \& Aithal, P. S. (2018). Concept of Ideal Water Purifier System to Produce Potable Water and its Realization Opportunities using Nanotechnology. International Journal of Applied Engineering and Management Letters (IJAEML), 2(2), 8-26.

[31] Li, P., Wang, C., Zhang, Y., \& Wei, F. (2014). Air filtration in the free molecular flow regime: a review of high-efficiency particulate air filters based on carbon nanotubes. Small, 10(22), 4543-4561.

[32] Gabal, E., Chatterjee, S., Ahmed, F. K., \& Abd-Elsalam, K. A. (2020). Carbon nanomaterial applications in air pollution remediation. In Carbon Nanomaterials for Agri-Food and Environmental Applications (pp. 133-153). Elsevier.

[33] Saleh, T. A. (2016). Nanocomposite of carbon nanotubes/silica nanoparticles and their use for adsorption of $\mathrm{Pb}$ (II): from surface properties to sorption mechanism. Desalination and Water Treatment, 57(23), 10730-10744.

[34] Nemoto, J., Saito, T., \& Isogai, A. (2015). Simple freeze-drying procedure for producing nanocellulose aerogel-containing, high-performance air filters. ACS applied materials \& interfaces, 7(35), 1980919815.

[35] Zhong, Z., Xu, Z., Sheng, T., Yao, J., Xing, W., \& Wang, Y. (2015). Unusual air filters with ultrahigh efficiency and antibacterial functionality enabled by $\mathrm{ZnO}$ nanorods. ACS applied materials \& interfaces, 7(38), 21538-21544.

[36] Pastor, A., Balbuena, J., Cruz-Yusta, M., Pavlovic, I., \& Sánchez, L. (2019). ZnO on rice husk: A sustainable photocatalyst for urban air purification. Chemical Engineering Journal, 368(1), 659-667.

[37] Siva, S., Sudharsan, S., \& Kannan, R. S. (2015). Selective Co (ii) removal from aqueous media by immobilizing silver nanoparticles within a polymer-matrix through a formaldehyde cross linking agent. RSC Advances, 5(30), 23340-23349.

[38] Baltrusaitis, J., Jayaweera, P. M., \& Grassian, V. H. (2011). Sulfur dioxide adsorption on TiO2 nanoparticles: influence of particle size, coadsorbates, sample pretreatment, and light on surface speciation and surface coverage. The Journal of Physical Chemistry C, 115(2), 492-500.

[39] Wang, C., Sun, R., Li, X., Sun, Y., Sun, P., Liu, F., \& Lu, G. (2014). Hierarchical flower-like $\mathrm{WO}_{3}$ nanostructures and their gas sensing properties. Sensors and Actuators B: Chemical, 204(1), 224-230.

[40] Souzandeh, H., Wang, Y., \& Zhong, W. H. (2016). "Green” nano-filters: fine nanofibers of natural protein for high efficiency filtration of particulate pollutants and toxic gases. RSC advances, 6(107), 105948105956.

[41] García, A., Delgado, L., Torà, J. A., Casals, E., González, E., Puntes, V., ... \& Sánchez, A. (2012). Effect of cerium dioxide, titanium dioxide, silver, and gold nanoparticles on the activity of microbial communities intended in wastewater treatment. Journal of hazardous materials, 199(1), 64-72.

[42] Li, K., Li, C., Tian, H., Yuan, L., Xiang, A., Wang, C., ... \& Rajulu, A. V. (2020). Multifunctional and 
Efficient Air Filtration: A Natural Nanofilter Prepared with Zein and Polyvinyl Alcohol. Macromolecular Materials and Engineering, 305(8), 2000239.

[43] Rodrigues, P. A. F., Geraldes, M. J., \& Belino, N. J. (2011, March). Legionella: Bioactive nano-filters for air purification systems. In 1st Portuguese Biomedical Engineering Meeting (pp. 1-2). IEEE.

[44] Wang, S. J., Zhang, X. Y., Su, D., Wang, Y. F., Qian, C. M., Zhou, X. R., ... \& Zhang, T. (2020). Electrospinning Ag-TiO2 Nanorod-Loaded Air Treatment Filters and Their Applications in Air Purification. Molecules, 25(15), 3369.

[45] Ghorani, B., Kadkhodaee, R., Rajabzadeh, G., \& Tucker, N. (2019). Assembly of odour adsorbent nanofilters by incorporating cyclodextrin molecules into electrospun cellulose acetate webs. Reactive and Functional Polymers, 134(1), 121-132.

[46] Rafique, M. S., Tahir, M. B., Rafique, M., \& Shakil, M. (2020). Photocatalytic nanomaterials for air purification and self-cleaning. In Nanotechnology and Photocatalysis for Environmental Applications (pp. 203-219). Elsevier.

[47] Tang, X., Wang, X., Yang, L., Zhang, Z., Luo, J., \& Wang, J. (2020). Multifunctional nickel nanofiber for effective air purification: PM removal and NO reduction from automobile exhaust. Journal of Materials Science, 55(14), 6161-6171.

[48] Yeo, J. H., Kim, M., Lee, H., Cho, J., \& Park, J. (2020). Facile and Novel Eco-Friendly Poly (Vinyl Alcohol) Nanofilters Using the Photocatalytic Property of Titanium Dioxide. ACS omega, 5(10), 50265033.

[49] Yunoki, M., Yamamoto, S., Tanaka, H., Nishigaki, H., Tanaka, Y., Nishida, A., ... \& Yoshikawa, M. (2008). Extent of hepatitis E virus elimination is affected by stabilizers present in plasma products and pore size of nanofilters. Vox sanguinis, 95(2), 94-100.

[50] Kim, J. P., Kim, J. H., Kim, J., Lee, S. N., \& Park, H. O. (2016). A nanofilter composed of carbon nanotubesilver composites for virus removal and antibacterial activity improvement. Journal of Environmental Sciences, 42(1), 275-283.

[51] Ruiz, O. N., Brown, N. A., Fernando, K. S., Harruff-Miller, B. A., Gunasekera, T. S., \& Bunker, C. E. (2015). Graphene oxide-based nanofilters efficiently remove bacteria from fuel. International Biodeterioration \& Biodegradation, 97(1), 168-178.

[52] Vijay, Y. K., Bhagwat, P. V., Nathawat, R., \& Nair, J. P. (2009). Large scale production of nanofilter. In Proceedings of the DAE-BRNS Indian particle accelerator conference. https://www.rrcat.gov.in/inpac/downloads/inpac/papers/52\%20.pdf

[53] Zhang, Q., Li, Q., Young, T. M., Harper, D. P., \& Wang, S. (2019). A novel method for fabricating an electrospun poly (vinyl alcohol)/cellulose nanocrystals composite nanofibrous filter with low air resistance for high-efficiency filtration of particulate matter. ACS Sustainable Chemistry \& Engineering, 7(9), 87068714.

[54] Gao, X., Li, Z. K., Xue, J., Qian, Y., Zhang, L. Z., Caro, J., \& Wang, H. (2019). Titanium carbide Ti3C2Tx (MXene) enhanced PAN nanofiber membrane for air purification. Journal of Membrane Science, 586(1), 162-169.

[55] Aithal, P. S. \& Shubhrajyotsna Aithal (2018). The Concept \& Characteristics of Ideal Energy System and its Realization Constraints. International Journal of Applied Engineering and Management Letters (IJAEML), 2(2), 127-137.

[56] Shubrajyotsna Aithal \& Aithal, P. S. (2018). Concept of Ideal Water Purifier System to Produce Potable Water and its Realization Opportunities using Nanotechnology. International Journal of Applied Engineering and Management Letters (IJAEML), 2(2), 8-26.

[57] Ibrahim, R. K., Hayyan, M., AlSaadi, M. A. et al. (2016). Environmental application of nanotechnology: air, soil, and water. Environ Sci Pollut Res., 23(1), 13754-13788. 
[58] Aithal, P. S. and Shubrajyotsna Aithal (2016). Nanotechnology Innovations and Commercialization Opportunities, Challenges \& Reasons for Delay. International Journal of Engineering and Manufacturing (IJEM), 6(6), 15-25.

[59] Aithal, P. S. \& Shubhrajyotsna Aithal (2016). A New Model for Commercialization of Nanotechnology Products and Services. International Journal of Computational Research and Development, 1(1), 84-93.

[60] Aithal P. S. \& Shubhrajyotsna Aithal (2016). Business Strategy for Nanotechnology based Products \& Services. International Journal of Management Sciences and Business Research (IJMSBR), 5(4), 139-149.

[61] Aithal P. S. \& Shubhrajyotsna Aithal (2018). Nanotechnology based Innovations and Human Life Comfortability -Are we Marching towards Immortality? International Journal of Applied Engineering and Management Letters (IJAEML), 2(2), 71-86.

[62] Aithal, P. S., Shailashree, V., \& Kumar, P. M. (2015). A new ABCD technique to analyze business models \& concepts. International Journal of Management, IT and Engineering, 5(4), 409-423.

[63] Aithal, P. S. (2016). Study on ABCD analysis technique for business models, business strategies, operating concepts \& business systems. International Journal in Management and Social Science, 4(1), 95-115.

[64] Aithal, P. S. (2017). ABCD Analysis as Research Methodology in Company Case Studies. International Journal of Management, Technology, and Social Sciences (IJMTS), 2(2), 40-54.

[65] Shenoy, V., \& Aithal, P. S. (2016). ABCD Analysis of On-line Campus Placement Model. IRAInternational Journal of Management \& Social Sciences, 5(2), 227-244.

[66] Aithal, P. S., Shailashree, V., \& Kumar, P. M. (2016). Application of ABCD Analysis Framework on Private University System in India. International Journal of Management Sciences and Business Research, 5(4), 159-170.

[67] Aithal, P. S., \& Kumar, P. M. (2016). CCE Approach through ABCD Analysis of 'Theory A' on Organizational Performance. International Journal of Current Research and Modern Education (IJCRME), 1(2), 169-185.

[68] Shenoy, V., \& Aithal, P. S. (2017). Quantitative ABCD Analysis of IEDRA Model of Placement Determination. International Journal of Case Studies in Business, IT and Education (IJCSBE), 1(2), 103113.

[69] Aithal, P. S., Shailashree, V., \& Kumar, P. M. (2016). ABCD analysis of Stage Model in Higher Education. International Journal of Management, IT and Engineering, 6(1), 11-24.

[70] Aithal, S., \& Aithal, P. S. (2016). ABCD analysis of Dye-doped Polymers for Photonic Applications. IRAInternational Journal of Applied Sciences, 4(3), 358-378.

[71] Aithal, P. S., Shailashree, V., \& Kumar, P. M. (2015). Application of ABCD Analysis Model for Black Ocean Strategy. International Journal of Applied Research, 1(10), 331-337.

[72] Raj, K., \& Aithal, P. S. (2018). Generating Wealth at the Base of the Pyramid-A Study using ABCD Analysis Technique. International Journal of Computational Research and Development (IJCRD), 3(1), 68-76.

[73] Aithal, P. S., Shailashree, V. T., \& Kumar, P. M. (2016). Analysis of ABC Model of Annual Research Productivity using ABCD Framework. International Journal of Current Research and Modern Education (IJCRME), 1(1), 846-858.

[74] Aithal, P. S. (2017). ABCD Analysis of Recently Announced New Research Indices. International Journal of Management, Technology, and Social Sciences (IJMTS), 1(1), 65-76.

[75] Aithal, A., \& Aithal, P. S. (2017). ABCD Analysis of Task Shifting-An optimum Alternative Solution to Professional Healthcare Personnel Shortage. International Journal of Health Sciences and Pharmacy (IJHSP), 1(2), 36-51. 
[76] Aithal, P. S., \& Aithal, S. (2018). Factor \& Elemental Analysis of Nanotechnology as Green Technology using ABCD Framework. International Journal of Management, Technology, and Social Sciences (IJMTS), 3(2), 57-72.

[77] Aithal, P. S., Shailashree, V., \& Kumar, P. M. (2016). The study of new national institutional ranking system using $\mathrm{ABCD}$ framework. International Journal of Current Research and Modern Education (IJCRME), 1(1), 389-402.

[78] Aithal, P. S., Shailashree, V., \& Kumar, P. M. (2016). Factors \& Elemental Analysis of Six Thinking Hats Technique Using ABCD Framework. International Journal of Advanced Trends in Engineering and Technology (IJATET), 1(1), 85-95.

[79] Aithal, P. S., Shailashree, V., \& Kumar, P. M. (2016). Analysis of NAAC Accreditation System using ABCD framework. International Journal of Management, IT and Engineering, 6(1), 30-44.

[80] Aithal, P. S., \& Aithal, S. (2017). Factor Analysis based on ABCD Framework on Recently Announced New Research Indices. International Journal of Management, Technology, and Social Sciences (IJMTS), 1(1), 82-94.

[81] Moridi A, Yarahmadi R, Abedi Z. (2020). Prioritizing new air pollution (gases and vapours) technologies based on CBA (Cost-Benefit Analysis) method. Iran Occupational Health, 17(6), 1-2. http://ioh.iums.ac.ir/article-1-2435-en.pdf

[82] Aithal, P. S. (2019). Information Communication \& Computation Technology (ICCT) as a Strategic Tool for Industry Sectors. International Journal of Applied Engineering and Management Letters (IJAEML), 3(2), 65-80.

[83] Aithal, P. S., \& Aithal, S. (2019). Management of ICCT underlying Technologies used for Digital Service Innovation. International Journal of Management, Technology, and Social Sciences (IJMTS), 4(2), 110136.

[84] Aithal, P. S., \& Aithal, S. (2019, October). Digital Service Innovation Using ICCT Underlying Technologies. In Proceedings of International Conference on Emerging Trends in Management, IT and Education (Vol. 1, No. 1, pp. 33-63).

[85] Aithal, P. S. (2018, December). Emerging Trends in ICCT as Universal Technology for Survival, Sustainability, Differentiation, Monopoly and Development. In Proceedings of National Conference on Advances in Information Technology, Management, Social Sciences and Education, (pp. 130-141).

[86] Aithal, P. S., \& Madhushree, L. M. (2019). Emerging Trends in ICCT as Universal Technology for Strategic Development of Industry Sectors. Chapter in a Book-IT and Computing for all the Domains and Professionals: The Emergence of Computer and Information Sciences, Edited by PK Paul, A. Bhuimali, KS Tiwary, and PS Aithal published by New Delhi Publishers, New Delhi. New Delhi, 1-26.

[87] Madhushree, L. M., Radhakrishnan, R., \& Aithal, P. S. (2019). A Review on Impact of Information Communication \& Computation Technology (ICCT) on Selected Primary, Secondary, and Tertiary Industrial Sectors. Saudi Journal of Business and Management Studies, 4(1), 106-127.

$* * * * * * * * * *$ 